\title{
TIME AND ETERNITY IN THE THEOLOGY OF ICONS
}

\section{Vladimir CVETKOVIĆ*}

\begin{abstract}
The aim of the paper is to elucidate the role of time and eternity in the theology of icons, by focusing on the artistic language of Orthodox iconography. The Orthodox iconography has developed a specific artistic language in order to express very complex theological and metaphysical issues such as the relationship between time and eternity. By using exclusively artistic elements such as light, colours and perspective, this symbolic language finds the appropriate way to visually articulate specific dogmatic themes that link the historical with the eschatological realm. The light is the essential element of the icon, because the light is identified with the uncreated energies of God that constitutes the future reality. While light gives this eternal perspective to the saints and events, the sketches made according to eikonismos preserve the likeness of the depicted image with the saint. Colours symbolically represent the diapason from being as a divine gift conferred to every creature at the creation to the eternal well being as a gift of God conferred to the holy people and angels at the end of time. The combination of inverse, central and axonometric perspective scales persons and objects according to geometry of value and position, rather than to a spatial geometry. The divine eternity causes the lack of spatial and temporal distance between persons and objects and their position and value depends on the relation with God.
\end{abstract}

Keywords: theology of icons, time, eternity, light, coulors, perspective

\section{Introduction}

The Christian understanding of time was shaped by something genuinely new and unique, the Incarnation of God in human form. Since

* Ph.D., PhD, independent scholar, Göttingen, Germany; honorary research associate of the University of Belgrade. 
the complete revelation of the God's work happened in the Person of Jesus Christ, he became the ultimate reference for the Church in regard to the fulfillment of time. Therefore, the future does not bear decisive significance for Christians like it does for the Jews, because it could not be a greater revelation of God in history than occurred in the Incarnation. This does not however mean that the Christians by commemorating past events from Christ's life are oriented permanently toward the past. In spite of the fact that the Incarnation as the perfect and complete revelation of the divine work was in the past, the appropriation of this revelation by a greater number of people belongs to the future realm or the Kingdom of God. The Christian understanding of time and eternity is shaped by both the commemoration of the historical events and persons and the expectation of the realization of the glorious kingdom. Since time points continually to eternity, time is brought to completion at each of its moments and therefore eternity does not begin at the end of history, but it contains and transforms time. Thus, for Christians the kingdom is placed, not only after the end of history, but also after each particular moment of time within history, due to the participation in the kingdom of God through faith and through communion in the holy sacraments in this present life. In order to express these complex theological and metaphysical issues such as the relationship between time and eternity, the Orthodox iconography has developed a specific artistic language.

This paper, therefore, sets out to explore how by using exclusively artistic elements such as light, colours, forms and perspective, the Orthodox iconographers found the appropriate way to visually articulate specific dogmatic themes that link the historical with the eschatological realm. In discussing the symbolic language of Orthodox iconography, I will begin by looking at the way in which drawings, light and colours express both the historical and eternal perspective of the depicted persons and events. Next, I will turn to the role, which various perspectives, such as reverse, central and axonometric, play in depicting the interplay between time and eternity. The paper will end with a discussion of two different artistic techniques: one that depicts two or more successive moments in time in one single representation, known as the summation of visual impressions, and the other that repeats within the limits of a single representation a certain figure in various moments in time, the technique referred to as the complex translation. 


\section{Light, Drawings and Colours}

The light is the essential element of the icon, because the light is identified with the uncreated energies of God that permeate the Kingdom of God. While light gives this eternal perspective to the saints and events, the sketches made according to eikonismos (depiction) preserve the likeness of the depicted image of the saint. By the combination of light and drawings the iconographer depicts the events and persons from the historical and temporal world, transfigured into the world-to-come. The drawing represents the specific historical events or persons and their historical links either with Christ, like in the case of the apostles, or with the particular ecclesial community, which keeps their memory. Thus, one may without difficulty recognize that the saint who touches Christ's wounds is St Thomas, or that the bishop who is standing on the boat and calming the see is St Nicholas. The drawing emphasizes the historical characteristics of the depicted persons. The light, often depicted in yellow or gold, stresses the eschatological perspective, or the fact that the persons depicted appear not in their earthly state, but as transfigured in the Kingdom of Heaven. Both elements have a theological significance and therefore it is highly important for the iconographer to keep them in perfect balance in order to transmit the right message of the icon. The perfect balance between drawing and light in the icon does not mean that their roles are equal in representing the deified reality. The light gives the true meaning to the icon by liberating the depicted events or persons from the temporal and the biological existence confined by drawing. The purpose of the light is not to decorate the depicted scenes or persons, but to establish their true and eternal identity. Theologically, this light is identified with the divine and uncreated energies of God.

There are many biblical testimonies of the occurrence of divine light, but probably the most famous emergence of the divine and uncreated light is connected to Christ's Transfiguration on the Mount Tabor, when he appeared transfigured with the face that 'shone like the son, and the garments [that] become white as light' (Mt 17,2), accompanied by Moses and Elijah. In the patristic sources God is often identified with light. In the Nicene-Constantinopolitan Creed the begetting of the Son from the Father is described as generation of 'light 
from light'. One of the purposes of the early icons of martyrs from the catacombs, apart from the explanation of the importance of the liturgy, which is celebrated in the glory of a certain martyr, was also to represent a martyr in front of God in the Kingdom of Heaven. The martyr is depicted as transformed and enlightened by the divine light, which is from the $4^{\text {th }}$ century onwards transformed into a halo as a sign of his or her sainthood $^{1}$. The halo represents a confirmation of God the Father that the saint is received in the Heavenly Kingdom and it is not a decorative, but an ontological characteristic of the icon. The reference that these halos or crowns of the saints 'are not created things' can be found in the Macarian homilies ${ }^{2}$.

St. Symeon the New Theologian's account on light may give us a clue regarding the characteristics of the uncreated light. St. Symeon's claims that the divine light 'shines on us without evening, without change, without alternation, without form' ${ }^{3}$ describe quite aptly the characteristics of the light on the icon. First, being without evening means that the light of the icon is not from a natural source, like the light of the sun, which shines only from the sunrise until sunset. Therefore, the light of the icon is not a combination of light and shade that suggests the existence of the natural source of light, which illuminates the object from one side or another. However, this does not mean that all the objects of the icon are equally illuminated. The light on the Byzantine icon is not an addition to the beings, which already exists, but it constitutes the same existence of the depicted persons.

The second characteristic that St. Symeon states in his description of the divine light is the lack of change and alternation. This permanent and never ceasing light of the Byzantine icon creates a constant in the depiction of certain objects. For example, the trees depicted on the icon never lose their leaves. However, this constancy in depiction derives from the fact that all depicted objects are incorruptible and they do not cease to exist due to the unfading light, which constitutes their existence.

Third, St. Symeon claims that the divine light is without form. This does not mean that the divine light is completely formless, but that it does

${ }^{1}$ Henry MaguiRe, The Icons of Their Bodies, Princeton: PUP 1996, p. 38-40.

${ }^{2}$ Macarius of Egypt, Homily 6, 7 (PG 34, 524A).

${ }^{3}$ St. Symeon the New Theologian, The Discourses, London: SPCK, 1980, p. 298. 
not follow the natural laws to which the created light is subjected. One of these natural laws is the linear motion. Therefore, the people in the scenes are always centrally unlighted, and there is no dialectic of light and shadow like in the case when the light falls from one source. The light of the icon is not only free from the necessity of natural motion, but it also frees the depicted persons and objects from natural causality. It creates the atmosphere of weightlessness of the depicted persons and objects. The depiction of saints as standing on their toes, more like levitating, creates the impression that the persons and objects on the icon are not subjected to the law of gravity. The light also gives a sort of weightlessness to the buildings or hills, which sometimes look like they are leaning to one side but without tendency to fall down.

It has been frequently asserted that the source of light on the icon is internal and not external ${ }^{4}$. St. Symeon's words help us again to understand the meaning of this internal light. By saying that the divine light 'speaks, works, lives, gives life, and changes into light those to whom it illuminates', Symeon clearly states that the light of the saints is the result of their sanctification by God who is the light. Therefore, Stamatis Skliris rightly argues that ontologically the source of the light is external, in the sense that it is out of the creation ${ }^{6}$. This external light is the uncreated light of the Triune God, which, if it is adopted by the saints, becomes their own, not as characteristics of their nature, but as a gift of God. The shadows caused by the nose or the chin of a saint clearly show that the source of the light comes from outside. If the source of light dwells in saints, then there would not be shadows on their faces. The characteristic of this light, which comes from the enormous distance of the other realm, is that it illuminates the saints centrally. The rays are parallel and fall vertically on the surface of the icon, creating a centripetal lightening on each figure. As we said above, this light constitutes the beings depicted on the icon, because only be participating in the divine light, the beings take part in life.

${ }^{4}$ Boris Uspensky, The Semiotics of the Russian Icon, Lisse: The Peter de Ridder Press 1976, p. 37.

${ }^{5}$ St. Symeon the New Theologian, The Discourses, p. 298.

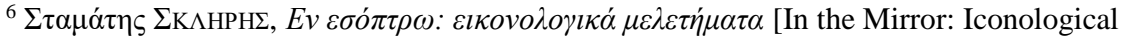

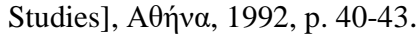


The iconographer expresses the theological concept of the transition of the creation from non-being to being, and from being to eternal being by artistic means as the transition from dark to light, shapelessness to shape. It practically means that saints, who have freely attained the likeness of Christ, are depicted in bright colours, with the gold leaf background and the halos that surround their heads. On the contrary, the demons by refusing the love of God do not participate in the fullness of being. Consequently, the iconographer always depicts demons in dark colours. However, these dark colours are not qualitatively equal to the bright colours, because they are more the lack of the light and in this sense they resemble evil, which is lack of good and it does not have ontological existence. While the technology of icons consists of painting from dark colours (proplasma) to lighter ones, the demons always remain depicted in the first and the darkest layer of the icon.

\section{Perspective}

The perspective also enabled the iconographer to transmit theological ideas about the reality of the Kingdom of God. The icon does not replace the reality that it represents, but it rather leads us through itself so we can meet the reality itself. Thus, the icons like the Eucharist are 'images' of the future things. The theological idea that the depicted people and events dwell in the divine presence is artistically transmitted by perspective. Perspective also expresses our belief that the holy people intercede in front of God for us. Thus, the function of the perspective is not to establish a relationship between the spectator and the icon, but a relationship between God and the spectator through the icon. The subject of this process is not an objective spectator any longer, rather it becomes rather the object of perception itself. Therefore, the perspective of looking at the icon is also changed, because we are not anymore spectators, instead, we become the objects of the icon's gaze ${ }^{7}$. The gaze of icon is the gaze of God, what creates an impression that by looking at the icon, the spectator is seen by God through the icon. The 'internal viewingpoint' of icon, which is on 'the other side' of the image is as an optical

7 John Panteleimon Manoussakis, "The Anarchic Principle of Christian Eschatology in the Eucharistic Tradition of the Eastern Church", in Harvard Theological Review, no. 1//2007, p. 44. 
fixed point. The old practice of an iconographer to paint first a great eye on the empty canvas and to write underneath the word 'God' proves that the icons are not seen just as windows towards eternity but also as heaven's windows towards earth ${ }^{8}$. By locating the vanishing point in which the lines converge not in some fictitious space outside the icon, but in front of the panel the iconographer expressed the theological belief that by being present in front of icon, like being in the liturgical gathering we are in the presence of God. However, the simple reversion of the positions of the viewer and the viewed, of the view-point and the vanishing-point, does not mean that we arrive to a single vanishing-point in the viewer's space. There is no single 'vanishing-point' in the viewer's space, for each represented object or space has its own perspective ${ }^{9}$. Therefore, the 'inversion' is not simple, but it is rather the combination of few perspectives that creates a dynamic both away and towards the image. This dynamic helps the person, which is neither viewer nor subject to negotiate his or her way into participation with and within the image. While the inverse perspective helps to the person to participate within the image, in order to participate in the Kingdom, other two perspectives, central and axonometric (or isometric in particular) allow the relationship with the image ${ }^{10}$.

In the inverse perspective, the lines pass through the real space in front of the icon and converge in the spectator. By this perspective the iconographer has succeeded to transmit the reality of the threedimensional space not violating the plane of the panel by creating the optical illusion of deepness ${ }^{11}$. The inverse perspective does not distort our visual perception, by limiting our sensory experience on a single 'snapshot', but creates a complex psychological experience based on the synthesis of various sensations and various memories of the actual experiences of objects. This is not the perspective of a motionless spectator such as central, but is constituted by the synthesis of multiple images that are results of the movements made by our eyes and our and

${ }^{8}$ B. USPENSKY, The Semiotics of the Russian Icon, p. 39.

${ }^{9}$ Charles Lock, 'Iconic Space and the Materiality of the Sign', in Religion and the Arts 1/4 (Winter 1997), p. 8-9.

${ }^{10}$ Jean-Claude LARCHET, L'iconographe et l'artiste, Paris: Cerf, 2008, p. 47-48.

${ }^{11}$ Leonid OUSPENSKY / Vladimir LosSKY, The Meaning of Icons, New York: St Vladimir Seminary's Press 1982, p. 41. 
the movements in relation to objects.

The central perspective characterized by the lines that converge in some fictitious space behind the icon, introduces the impression of the third dimension. The central perspective is used in the icons but not systematically. It means that there is no single vanishing point in some factious space behind the icon, but each object represented by this perspective has its own vanishing point. The central perspective is used to represent certain objects or even parts of objects. For example, the house of Abraham or the chalice in the table depicted on Andrei Rublev's famous icon of Holy Trinity, are represented by central perspective.

The isometric perspective is a representation obtained by orthogonal projection where the lines, which are parallel in the real space, are not converging in one vanishing point, but they are also preserved parallel on the plane. By this perspective, which aims to represent the actual measurements or reductions, the certain objects that occupy a central position in the spatial geometry of central perspective are not holding the same dominant position any more. By using the isometric perspective the iconography aims to reduce the deformation of the physical world to a minimum.

It would be, however misleading to conclude that the aim of iconography is to transpose the world according to a spatial geometry. The iconography scales persons and objects according to geometry of value and position, rather than with spatial geometry ${ }^{12}$. The position and value of persons and objects depend on their relation with God and not on their place in time and space. The iconic space is always anthropocentric because the human being is the crown of creation and the mediator, but not anthropomonistic. The demons sometimes even depicted in the first plane are much smaller than they should be according to central perspective. Their size and their lack of light represent the position and value they have in relation to God. By representing the demons as sizeless and formless, the iconographer symbolically conveys their tendency toward nothingness at one side, but also the divine goodness, which keeps them in existence ${ }^{13}$.

12 C. Lock, "Iconic Space and the Materiality of the Sign", p. 8.

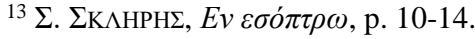




\section{Summation of Time and Space and the Complex Translation}

The iconographer uses often two ways to synthesize the experience of historical events that are extended in time. The first way could be defined as the summation of the visual impression, which is again twofold and can be the summation in time and the summation in space, while the second is referred to as complex translation ${ }^{14}$. The aim of the summation in time is to convey the movement of the depicted figure by combining different stages in the figure's motion or to convey the two or more successive moments in time in one single representation. Thus, the figures are sometimes presented in odd positions. For example, it is common to see that the head of a figure is turned at a 180 degrees angle relative to the torso. The representation of the figures in the state of certain movement does not signify that they are really moving in the plane. The lack of depth or the third dimension in the reverse perspective conveys another theological truth in regard with the space in icons. The movement is always connected with the time, from the time of Aristotle who defined time as number of movement. The iconic space like the space in the future Kingdom is not the extended space traversed by movement and measured by time. Due to lack of time the iconic space is transformed from space as extension to space as potentiality. Therefore, even the figures on icons are depicted in a state of flux it suggests more their internal spiritual dynamism than the traversing of the physically extended space.

There is also a method how to sum up experience of space, which is again connected with the extension in time. While the summation of space is expressed by the combining different stages of the same process or successive temporal points, without deformation of figure, the summation in space is considered as deformation of the object of summation. The best examples for the summation in space are rocks with many ledges and shelves and the building with many apertures and partitions. Here the summation is not attained by the dynamism of the depicted objects, but by the dynamics of the iconographer's visual position. This is the summation of the different visual positions of the iconographer in relation to the object. Therefore, the multiplicity of points

${ }^{14}$ B. USPENSKY, The Semiotics of the Russian Icon, p. 49-54. 
of view or the multi-point perspective is the synthesis of the images of the objects seen from different sides and different angles.

The second iconographic method of how to transmit time into eternity called the 'complex translation' is by the repetition of a certain figure in various positions or situations, that is, in various moments within the limits of single representation ${ }^{15}$. A good example of such a representation is the composition of The Beheading of St John the Forerunner, where the head is shown twice in different moments of time. Another example is The Assumption of the Mother of God when the soul of the Mother of God is depicted twice, once in the arms of Jesus, and the second time being carried by the angels.

Sometimes these multiple representations of the successive moments in a single scene are divided by borders, but here borders are not framing the scene, causing again the partition of time. They rather unite the different representations in one single scene, because they unite both the events extended in space at the same time, and the events extended in time at the same place. The scene of the Nativity illustrates this non-summative synthesis. The representations of the historical events are 'moments' of the kairos with their eternal significance. All these moments or אalpoí from the earthly life taken together presuppose eternal existence in the future Kingdom. Thus, the icons are not simply the photographs or the portraits of Christ, the Mother of God and the saints from one or another phase of their earthly lives, but the depiction of their lives in the future deified state, consisting of all these particular кalpoí when they glorified God on Earth.

The difference between the two artistic methods to transmit time into eternity with the help of perspective is transparent in the degree of the deformation of the object, but also in the degree of participation of both an iconographer and a viewer. In the case of summation of time and space the object appears deformed in the higher degree. Also the role of iconographer is active due to the synthesis of the visual impressions. In the second case of representation of separate moments in a single scene, the distortion or the deformation of the object is in lesser degree and the role of the spectator is emphasized, because the spectator rather than the iconographer unifies the separated moments in a single composition.

${ }^{15}$ Ibidem, p. 51. 


\section{Conclusion}

In conclusion, the Orthodox iconographers used different techniques in order to transmit the complex dialectics of time and eternity. By eikonismos or drawings of characteristic physiognomic features of persons and historical events they placed them within the concrete historical moment, but by clothing them in light they disconnected them from the past and transferred them to the divine eternity. By using the central and isometric perspective, the iconographers preserved the resemblance of the depicted objects with the created physical world and established the relationship between the spectators and depicted objects. However, by prioritization of the inverse perspective over the other two, the iconographer establishes the relationship between God and spectators through the icon, helping them to participate in divine eternity by partaking within the image. Finally, the summation of visual impressions, either by iconographer or viewer and the complex translation releases the created world from ontological necessity and attributes eternal significance to the moments (kairoi) of time.

\section{References}

1. LARCHET, Jean-Claude, L'iconographe et l'artiste, Paris: Éditions du Cerf, 2008.

2. LocK, Charles, "Iconic Space and the Materiality of the Sign", in Religion and the Arts 1/4 (Winter 1997), p. 6-22.

3. Macarius OF EgyPT, Homilies, PG 34.

4. Maguire, Henry, The Icons of Their Bodies, Princeton, NJ.: Princeton University Press 1996.

5. Manoussakis, John Panteleimon, "The Anarchic Principle of Christian Eschatology in the Eucharistic Tradition of the Eastern Church", in Harvard Theological Review, no.1/2007, p. 29-46.

6. OUSPENSKY, Leonid / LOSSKY, Vladimir, The Meaning of Icons, New York: St Vladimir Seminary's Press, 1982.

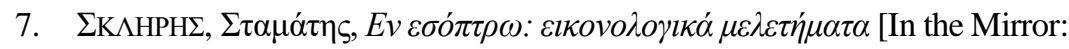

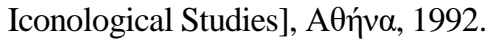

8. St. Symeon the New Theologian, The Discourses, London: SPCK, 1980.

9. UsPENSKY, Boris, The Semiotics of the Russian Icon, Lisse: The Peter de Ridder Press, 1976. 